\title{
REVIEW OF WATER RESOURCES AND MANAGEMENT IN SOUTH AFRICA
}

\author{
ELKINGTON SIBUSISO MNGUNI \\ Trans-Caledon Tunnel Authority, Centurion, South Africa
}

\begin{abstract}
South Africa is a water-scarce country. It is estimated that, based on current usage trends, water demand will exceed availability by 2025 . The continuing trend in industrialization and urbanization of the population is expected to place further pressure on the country's sources of water supply unless appropriate corrective action is taken. In general, adequate resources are available to meet all priority requirements until 2025, provided they are well managed. Substantial volumes can be made available through the increased wastewater re-use of return flows. Options for reconciling water requirements with availability include desalination, groundwater, rainwater harvesting and wastewater reclamation. The Department of Water and Sanitation is the custodian of South Africa's water resources. Major pieces of legislation affecting water have been outlined in the study. Key successes made by the water sector department since the dawn of democracy in 1994, have been highlighted. Key challenges that must be addressed to ensure long term sustainability of the water resources in the country have also been identified.
\end{abstract}

Keywords: water-scarcity, water resources, water availability, water requirement, supply, demand.

\section{INTRODUCTION}

This study reviews the availability of water against current and future demand in the country of South Africa within the context of global and regional water resources. It also looks at readily available water sources as well as those that must still be explored for long-term sustainability. A couple of success stories are identified as well as some challenges that must be addressed.

\section{BACKGROUND AND CONTEXT}

The context within which the case study was carried out is discussed in this section.

\subsection{Key features of the country}

The basic data provided by Stats SA [1] indicates that South Africa has a land area of 1.2 million $\mathrm{km}^{2}$ with nine provinces. Pretoria is the administrative capital, Cape Town the legislative capital and Bloemfontein the judicial capital. The time zone is at GMT +2 hours. The country has a diverse population of 58 million with eleven official languages and a gender split of $49 \%$ male and $51 \%$ female. The gross domestic product, at 2018 market prices, is ZAR 4.6 trillion (USD 272 billion). South Africa is a constitutional multiparty democracy with three spheres of government, namely, local, provincial and national spheres. The country's economy is amongst the largest in Africa.

\subsection{Water governance and management}

The Department of Water and Sanitation (DWS), under the leadership of the cabinet minister is responsible for developing and implementing legislation of water resources and services as well as sanitation services in the country. The acts of parliament that are currently in force are the National Water Act 1998 and the Water Services Act 1997 which guide the 
management of water resources and the provision of services to industrial, commercial and domestic users.

\subsection{Sector leadership and partnerships}

The DWS operates through its offices in nine provinces as shown in Fig. 1.

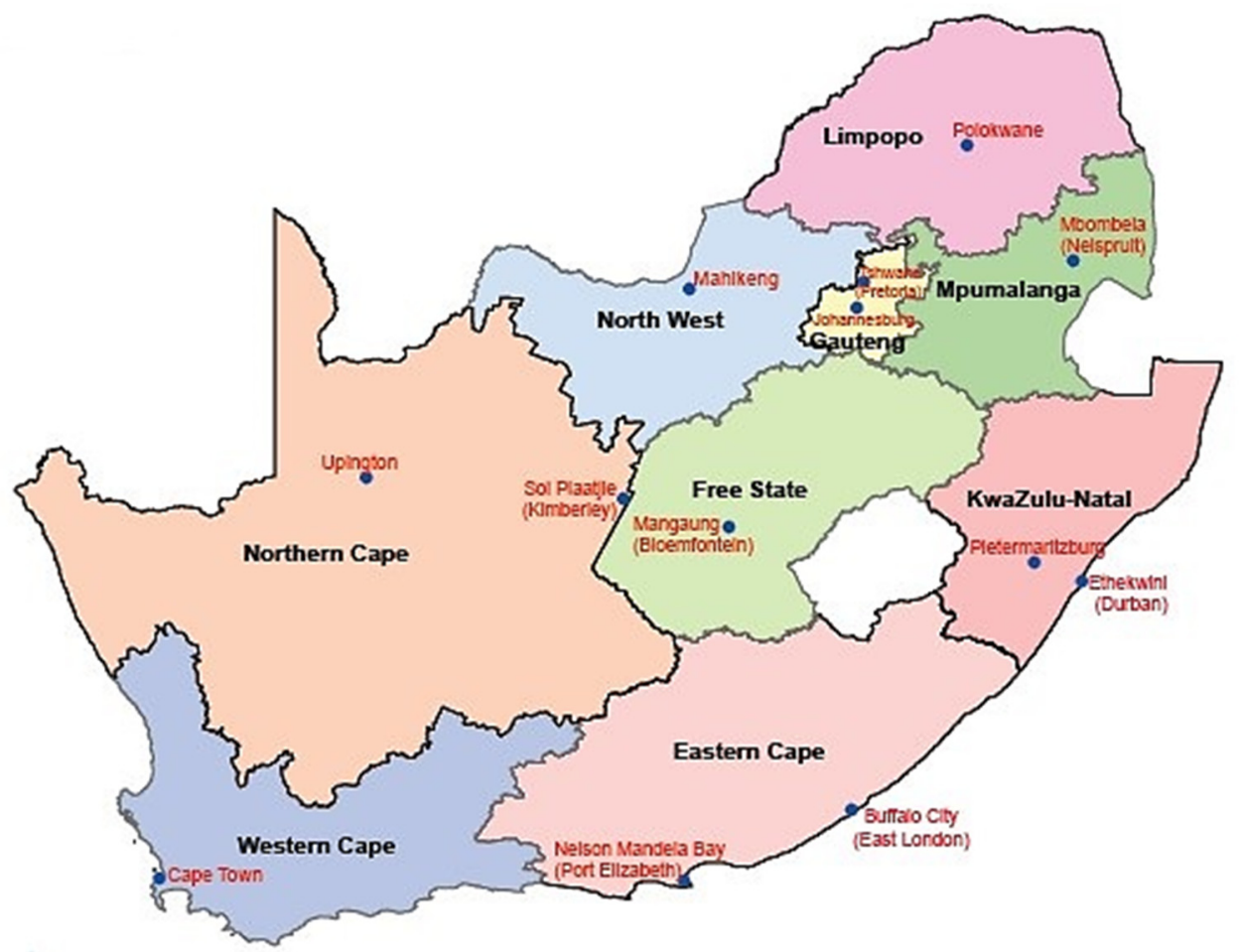

Figure 1: Map showing provinces of S. Africa. (Source: Republic of South Africa, Department of Water and Sanitation, 2017 [4].)

The DWS ensures compliance with quality norms and standards for potable water as well as for wastewater that is discharged into natural water courses and water bodies, i.e. the department oversees all aspects of water abstraction from various sources, treatment and distribution thereof to users as well as the collection, treatment and discharge of treated wastewater back to the natural environment. The department is also responsible for creating favourable conditions for continuous improvement in performance by sector participants and partners. The department holds ownership of the majority of large dams and plans and implements necessary infrastructure to ensure adequate and sustainable long-term water supply for all parts of the country.

Entities such as catchment management agencies and water user associations have been established in most areas with the responsibility of managing water resources in their respective areas. Fig. 2 shows the river-systems-based water management areas across the country. 
Key partners in the sustainable management of water resources include the Department of Environmental Affairs, the Water Research Commission, the Trans-Caledon Tunnel Authority and the Development Bank of Southern Africa, among others.

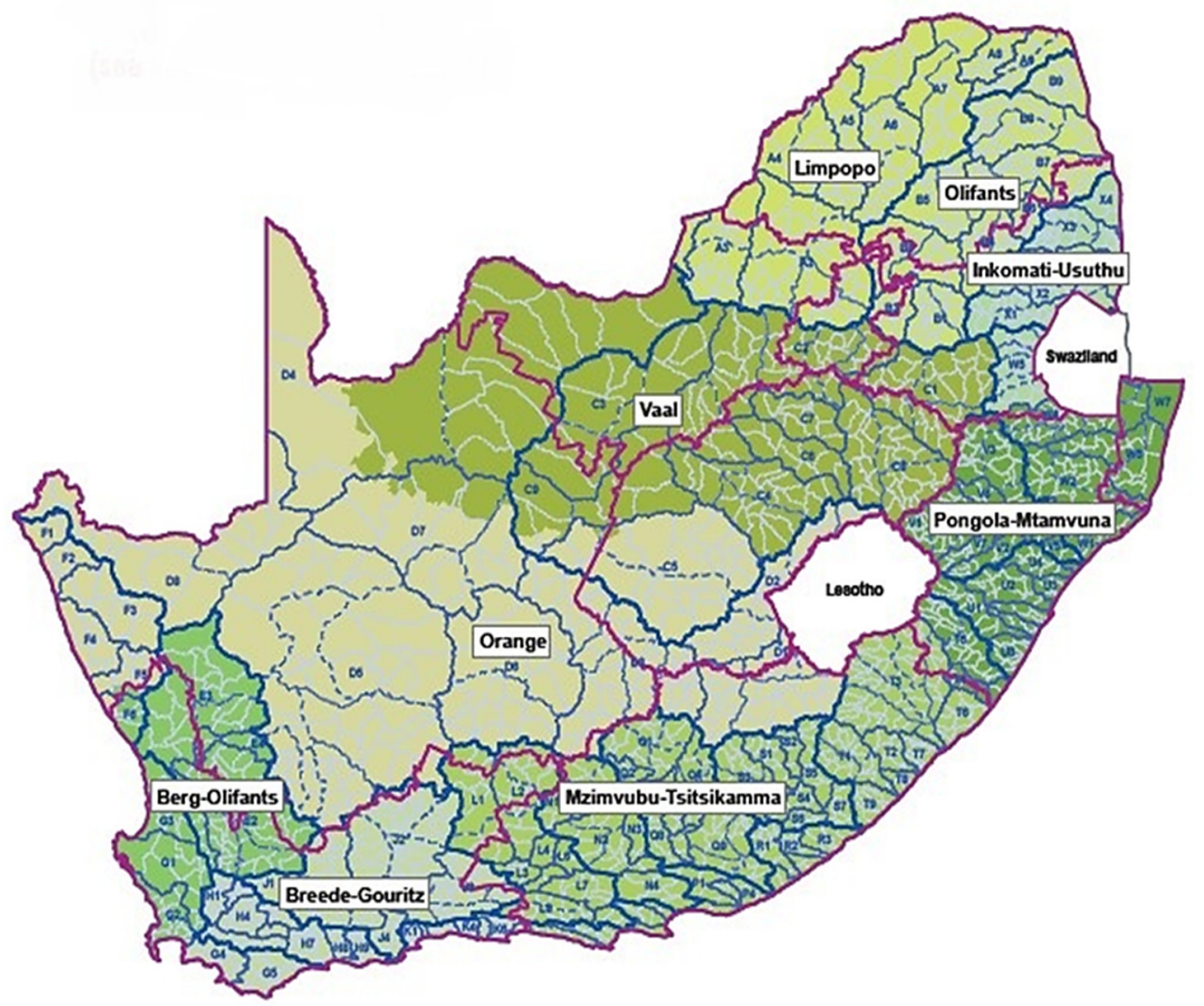

Figure 2: Water management areas based on river systems. (Source: Republic of South Africa, Department of Water and Sanitation, 2017 [4].)

\section{WATER RESOURCES}

This section discusses in detail the aspects of water resources and their management in South Africa.

\subsection{Global context}

The DWS [2] in its strategic plan provides a global context as detailed in this section. The strategic plan states that while there is a large amount of water on the planet earth, less than a percent is available as usable water which is estimated to be $90,000 \mathrm{~km}^{3}$. An amount of some $35,000 \mathrm{~km}^{3}$ cannot be extracted as it is frozen in the Antarctica and the Arctic as well as hidden in subterranean aquifers. Surface water on the earth is subject to the amount of runoff, evaporation and rainfall. The impact of these natural processes in various regions of the world is shown in Fig. 3 as published by the GRID-Arendal [3]. 


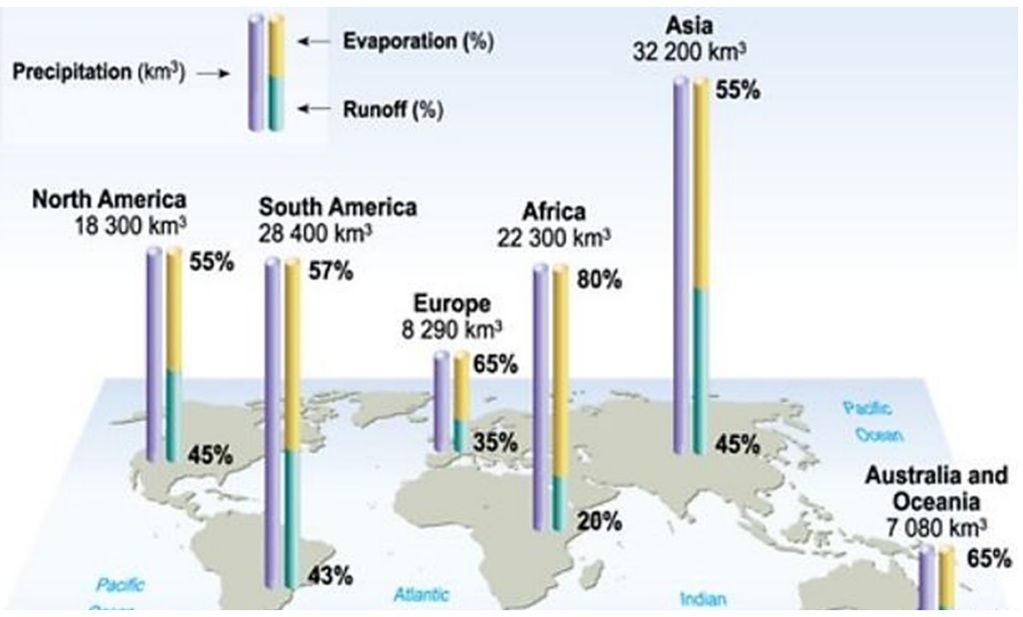

Figure 3: Rainfall, runoff and evaporation in the world. (Source: GRID Arendal [3].)

\subsection{Regional context}

The Southern African region is very dry with just over ten percent of the total volume of Africa's water. The eastern and northern countries in the region have relatively higher precipitation as shown in Fig. 4. South Africa is in the more arid section of the region and can be described as semi-arid with the eastern seaboard receiving relatively higher rainfall and the central region and the western seaboard receiving very little if any rainfall. Rates of evaporation in different parts of the country play a major role in the degree of aridity. Droughts are a regular occurrence and the quality of water is influenced negatively by the salts that dissolve from the underground rocks, especially in the Northern Cape province.

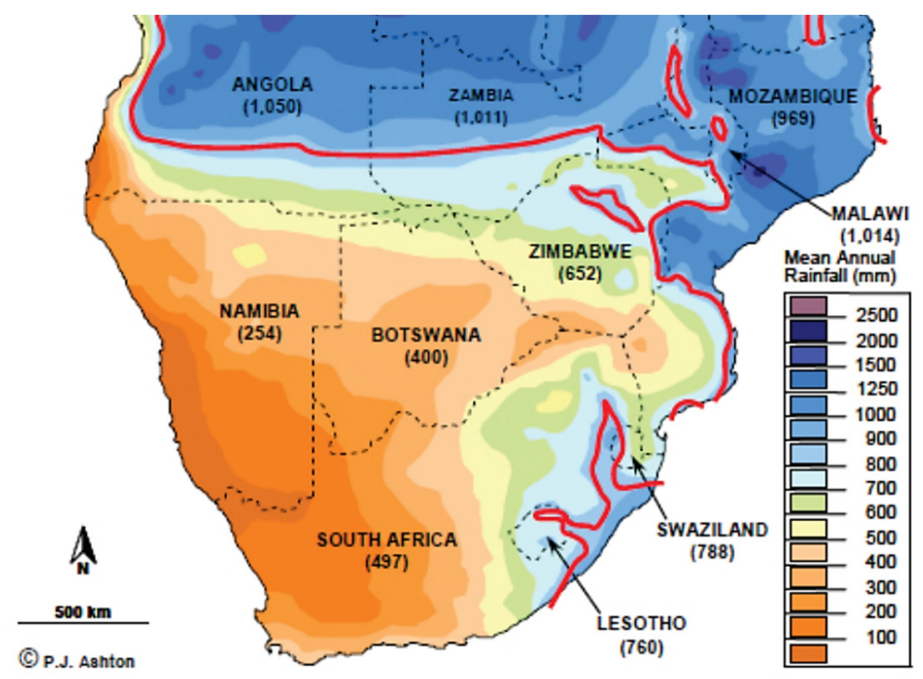

Figure 4: Annual average rainfall in Southern Africa. (Source: Republic of South Africa, Department of Water and Sanitation, 2017 [4].) 
South Africa shares six main rivers with countries of Namibia, Lesotho. Swaziland, Mozambique, Zimbabwe and Botswana with which it holds bilateral cooperation agreements.

According to Enviropaedia [5], some twenty percent of the country's land surface is the sources of more than sixty percent of the flows from rivers. This leads to an unequal distribution of available water across various regions of the country. To overcome this challenge some two-thirds of the average yearly precipitation is kept in dams to regulate excessive flooding and extreme droughts. The security of water supply is dependent largely on surface water. However, alternative sources like ground water and return flows need to be explored further to optimise their potential. This is particularly important because the utilisation of available freshwater is at its limit at this stage.

The Constitution of South Africa provides that everyone has the right to basic water supply and sanitation. However, the South African Human Rights Commission [6] reported that although great strides had been made over the 20 years of democracy, approximately $11 \%$ of formal and informal households (i.e. 1.4 million households in number) still need sanitation services meeting the legislated basic standards. In addition, during the 2011 Census $46.3 \%$ of households had access to piped water and over $85 \%$ had access to water at acceptable norms and standards level.

South Africa adopted the United Nation's post-2015 development agenda that identified 17 Sustainability Development Goals (SDGs) to carry the global sustainability development agenda to 2030. The water and sanitation sector is required to support the various sectors to meet the set targets within the 17 SDGs.

\subsection{Rainfall and water availability}

According to Hedden and Cilliers [7], South Africa is the 30th driest country globally with the mean annual precipitation of $450 \mathrm{~mm}$ compared to the global average of $860 \mathrm{~mm}$. The western seaboard receives barely a $100 \mathrm{~mm}$ while the eastern seaboard receives in excess of a 1,000 mm of rainfall in a year, as shown in Fig. 4. Climate change predictions indicate that the western half of the country will get progressively drier and that the eastern half will experience higher frequencies of extreme events like flooding and droughts.

\subsection{Water resources profile}

An integrated approach is required in order to ensure that available water resources are utilised and protected optimally by, among other measures, countering the effects of changeable rainfall patterns. The DWS manages the country's water resources to meet the objectives of ensuring a fair and sustainable distribution of water for socio-economic development to eliminate poverty, protect water, develop and support sound water management institutions, and orientate all those who are involved towards a vision of an integrated management of water resources. In order to achieve this the DWS owns more than 850 large dams which have a height of no less than $15 \mathrm{~m}$, or a wall height between $5 \mathrm{~m}$ and $15 \mathrm{~m}$ and a storage capacity exceeding 3 million $\mathrm{m}^{3}$. These dams can together store some 31 billion $\mathrm{m}^{3}$ of water.

Recently completed national water resource inter-basin transfer projects include the Spring Grove Dam to Mpofana transfer pipeline (KwaZulu-Natal province), the Komati Water Augmentation Scheme from the Vaal River System to the Komati River System, the De Hoop Dam to Steelpoort bulk pipeline (Limpopo province), the Mokolo-Crocodile River Water Augmentation Project's Phase 1 pipeline (Limpopo province). 
National water resource projects that are in preparation or early construction phases include the Mokolo-Crocodile River Water Augmentation Project's Phase 2 pipeline (Limpopo province), the Berg River Voelvlei Augmentation Scheme (Western Cape province), the uMkhomazi Water Project (KwaZulu-Natal province), the Raising of the Tzaneen Dam wall (Limpopo province), the Raising of the Clanwilliam Dam wall (Western Cape province), and the Lesotho Highlands Phase 2 (Polihali Dam and tunnel) which will provide much needed additional supply to South Africa by 2026.

\subsection{Water balance}

According to the National Water and Sanitation Master Plan [8], the country's surface runoff is in the order of 49 billion $\mathrm{m}^{3}$ per year of which about 15 billion $\mathrm{m}^{3}$ is a reliable yield at $98 \%$ assurance of supply. Of this yield, $13 \%$ is made up of return flows, $13 \%$ is groundwater, $6 \%$ desalination of brackish or sea water, and $68 \%$ surface water.

In terms of water usage, about 2.78 billion $\mathrm{m}^{3}$ per annum used is groundwater, while 17.1 billion $\mathrm{m}^{3}$ per annum used is surface water. The split of the surface water usage is roughly 5\% afforestation, $5 \%$ mining, $17 \%$ municipal, 18\% industrial and 55\% agriculture as shown in Fig. 5.

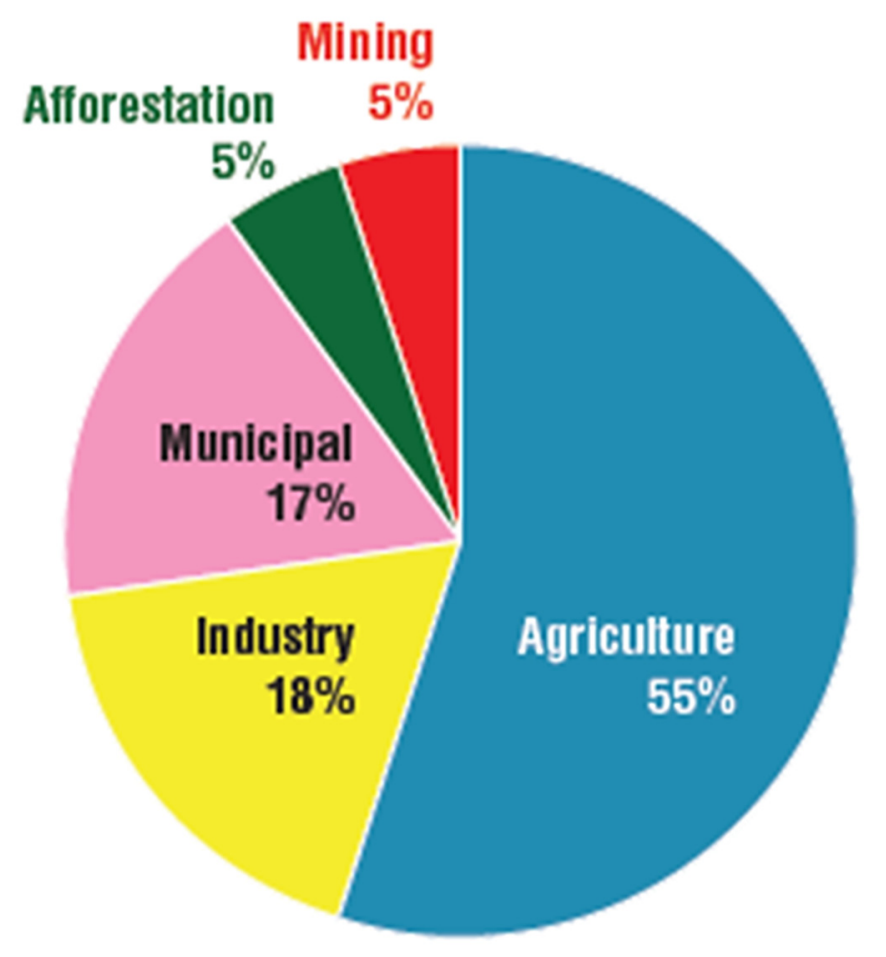

Figure 5: Water usage per economic sector. (Source: Republic of South Africa, Department of Water and Sanitation, 2017 [4].)

Total surface and groundwater usage is 19.88 billion $\mathrm{m}^{3}$ per year. The ecological reserve requires approximately 9.5 billion $\mathrm{m}^{3}$ per annum, while the total requirement for domestic 
use is about 4.5 billion $\mathrm{m}^{3}$ per annum. It is estimated that there could be an increase of about 7 billion $\mathrm{m}^{3}$ in rural and urban area usage in the next 30 years if water conservation measures are not put in place, increasing total usage to about 20 billion $\mathrm{m}^{3}$ per year.

According to DWS's Water Authorization and Registration Management System (WARMS) database, the total registered water usage, not actual use, has already reached the estimated 2025 high water requirement of 17.3 billion $\mathrm{m}^{3}$ per year. Current water usage already exceeds reliable yield in many water supply systems. This will mean that during a drought year it is likely that the affected area(s) will experience water restrictions more often on a fairly large scale and for longer periods. This is illustrated in Fig. 6.

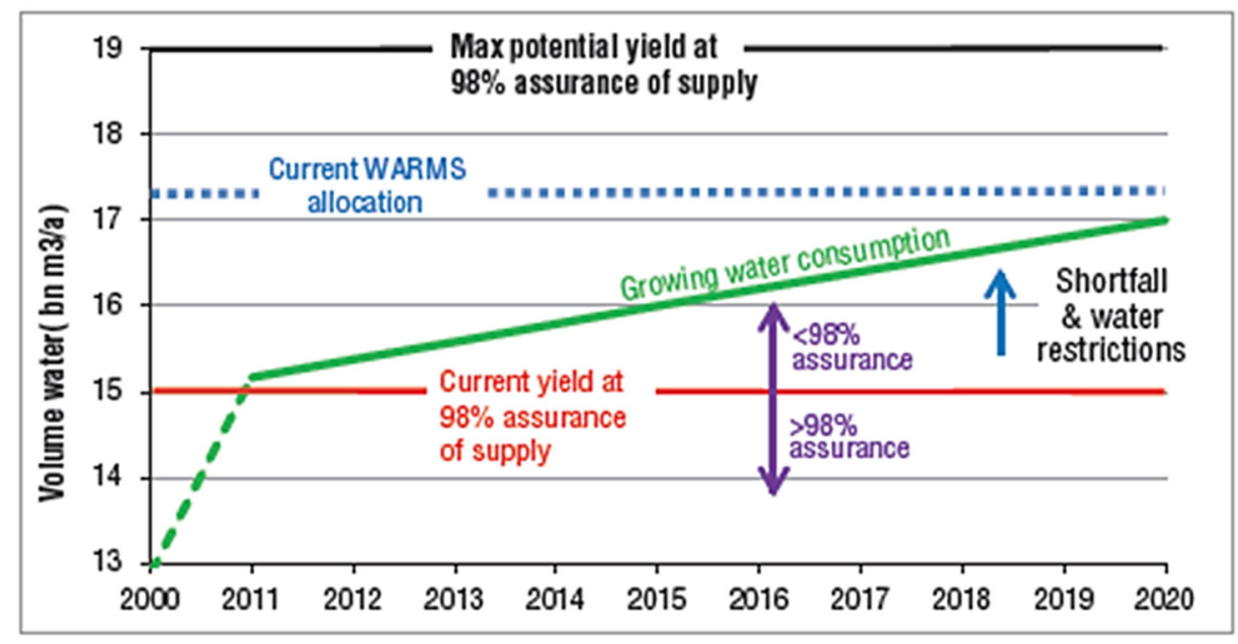

Figure 6: Water supply and demand trend. (Source: Republic of South Africa, Department of Water and Sanitation, 2017 [4].)

In order to meet future domestic water supply requirements water resources will need to be expanded accordingly. The "All-Towns Reconciliation Strategy Studies" of about 905 towns or clusters of villages indicates almost a third of the towns already have a shortage of water and need urgent interventions. A solution could be a combination of surface and ground water development as well as water conservation and demand management measures. Studies show that about $50 \%$ of the towns studied do not make budgetary provisions for such interventions and that non-revenue water stands at about $40 \%$.

Climate change is predicted to impact negatively on the adequacy of the country's water resources, both in terms of availability and storage requirements. DWS is monitoring the implementation of the recommendations of these reconciliation studies.

It is worth noting that although agriculture uses over $60 \%$ of our water, only $12 \%$ of South Africa's landmass is considered arable and only 3\% is considered to be truly fertile. Only $1.5 \%$ of the land is under irrigation, producing $30 \%$ of the country's crops, whilst $69 \%$ is given over to grazing and livestock farming. 


\subsection{Other water sources}

Growing water scarcity implies that municipalities will increasingly have to consider additional water sources such as discussed below.

\subsubsection{Seawater desalination}

Desalination requires a substantial amount of energy and is quite expensive to capital-fund and to operate but it is still less costly than the development of long-distance inter-basin transfers. A number of small seawater desalination plants have already been built along the South African coastline and small coastal towns are being supplied with desalinated sea water. The largest desalination plant in South Africa supplies 15 million litres per day (Ml/day) and is located at Mossel Bay.

With regard to coastal metropolitan cities, eThekwini (Durban, Umgeni Water Board), Nelson Mandela Bay Municipality, and the City of Cape Town have all undertaken feasibility studies to investigate whether sea water desalination is viable on a large scale (in excess of $100 \mathrm{Ml} /$ day). eThekwini Municipality has also initiated a study to look at a combination of sea water desalination and wastewater reclamation.

\subsubsection{Groundwater}

Groundwater is abstracted using boreholes or wells for potable use. The country's National Groundwater Strategy [9] states that "the unique, widely distributed groundwater resource, with its open access to a large number of users and a wide range of impacts, requires careful local level management of the shared groundwater resources within an appropriate enabling environment". The management and development of groundwater in South Africa is outlined in the strategy.

Groundwater has been overlooked in past but has now grown to be an invaluable source for domestic and general livelihood in the majority of communities in many small towns and villages countrywide. The quality of South African groundwater is generally of a potable standard and represent about $15 \%$ of the country's total water consumption.

The depth that has to be drilled to encounter groundwater ranges from $30 \mathrm{~m}$ and $60 \mathrm{~m}$ for large parts of the country, to more than $120 \mathrm{~m}$ under the deep sand cover in the Kalahari Desert. Groundwater development still has a high potential in the country.

In 2010, a revised water recharge strategy [10] was released to further advance the development of groundwater resources in the country. The strategy has a clear vision of maximising the use of natural sub-surface storage where it is technologically, economically, environmentally and socially feasible. Since groundwater's response to drought is much slower than surface water, artificial recharge can be used to create a buffer for times of drought.

\subsubsection{Stormwater harvesting}

Stormwater harvesting is a potential additional source of water that can supplement urban water supplies, as well as simultaneously offer a range of social and environmental benefits.

\subsubsection{Wastewater reclamation}

Wastewater reclamation for industrial and irrigation purposes conserves the available water supply, which reduces the need for more abstraction or provision of new infrastructure. It also reduces the volume of treated effluent discharged back into the aquatic system.

The town of Beaufort West has South Africa's first direct potable reuse plant, where treated wastewater effluent is conveyed directly to a water treatment facility for further 
treatment to drinking water standard. The plant contributes about $30 \%$ to the town's water supply. The town of George has a reclamation plant which functions as an indirect potable reuse plant, where treated wastewater effluent is discharged to the Garden Route Dam for dilution and storage before it is piped to the water treatment plant for further treatment. In Mossel Bay and Durban, water reclamation is used for industrial purposes.

Wastewater reclamation still requires increased technical capacity, institutional leadership and financial incentives. There is also a concern around the contaminants in wastewater that municipal wastewater treatment plants are not specifically designed to treat at present.

\subsubsection{Inter-river-basin transfers}

The distribution of water across the country is patchy and requires water to be transferred from areas of surplus to areas of shortage. There are 29 schemes which transfer water between river basins across the country whereby some 7,000 million $\mathrm{m}^{3}$ of water are transferred each year. An example is the second phase of the Lesotho Highlands Water Scheme which is currently being implemented to supply an additional 465 million $\mathrm{m}^{3}$ per annum to the country's economic hub, the Gauteng province.

\section{KEY SUCCESSES}

In terms of the DWS 2017 strategic overview, the following successes have been achieved:

- The DWS has developed a number of sound strategies, plans and policies which are crucial for the successful development and management of the country's water resources. Examples include the publication of the Second Edition of the National Water Resource Strategy, the development of the Reconciliation Strategies for its major demand centres, among others.

- More than 9.1 million households have been served with basic water supply, while more than 6.5 million households have been served with the minimum of a basic level of sanitation. The country also met the Millennium Development Goals targets with regard to the provision of water and sanitation services.

\section{KEY CHALLENGES}

In terms of the DWS 2017 strategic overview, the following key challenges must be addresses to ensure a sustainable supply of water into the future:

- There is no surplus water available and what water is available is unevenly distributed. Some $28 \%$ of the towns already have inadequate water, and climate change will worsen the situation. Water losses are too high as indicated by the non-revenue water being around $40 \%$.

- Due to the water shortages experienced in the country, the risk of pollution is high and leads to costly treatment interventions to mitigate such a risk. Moreover, a high number of wastewater treatment works are in a poor condition and often operate beyond their design capacities. The acid mine drainage makes the pollution problem worse, especially in the Vaal River System from where the country's economic hub of Gauteng is supplied.

\section{CONCLUSION}

This has been an interesting exercise which provided insights into the state of water resources in South Africa. It was good to see some of the achievements of the water sector department since the dawn of democracy in 1994. Key challenges were also identified that will need to 
be addressed going forward in order to ensure water security in the country in the short, medium and long terms.

\section{REFERENCES}

[1] Statistics South Africa (Stats SA), Sustainable Development Goals (SDGs) Country Report 2019 - South Africa. Statistic South Africa: Pretoria, p. 21, 2019.

[2] Republic of South Africa, Department of Water and Sanitation, Revised strategic plan (Vote 36) for the fiscal years 2015/16 to 2019/20, pp. 25-26, 2015.

[3] GRID Arendal, World's surface water: precipitation, evaporation and runoff. https://www.grida.no/resources/5827. Accessed on: 23 Apr. 2019.

[4] Republic of South Africa, Department of Water and Sanitation, Strategic overview of the water sector in South Africa, pp. 2-16, 2017.

[5] Enviropaedia, Rethinking reality. www.enviropaedia.com/topic/default.php?topic_id=240. Accessed on: 5 Jun. 2020.

[6] South African Human Rights Commission, Report on the right to access sufficient water and decent sanitation in South Africa, p. 45, 2014.

[7] Hedden, S. \& Cilliers, J., Parched prospects: The emerging water crisis in South Africa. African Futures Paper, 11, p. 2, 2014.

[8] Republic of South Africa, Department of Water and Sanitation, National Water and Sanitation Master Plan - Volume 2: Plan to Action, Version 4.2, pp. 10-11, 2018.

[9] Republic of South Africa, Department of Water and Sanitation, National groundwater strategy, p. vii, 2016.

[10] Republic of South Africa, Department of Water and Sanitation, Artificial recharge strategy, Version 2, p. 3, 2010. 